\title{
DRACULA AND THE RIGHTS OF HOSPITALITY: THE AXIS OF EVIL
}

\author{
MAXIMILIANO E. KORSTANJEL
}

\begin{abstract}
The present essay explores the archetype of Dracula, as well as its connection to hospitality. Although abundant literature has described the historical context that led Bram Stoker to present this personage, less attention has been paid to the impossibility as evil-doers Dracula does not honor the right of hospitality. Not only he is invited as guest by his victims, but hiding his real interests. Victorian society, in which the story is situated, faced serious problems with understanding and accepting "the Other", especially that which came from its colonies. Dracula not only defines the problem of what Kristeva dubbed "perverse hospitality", but also represents a diagnosis of the capitalist ethos. He seduces his victims by offering diverse banquets, food, and even sex. Dracula uses hospitality to meet his perverse needs. His real interests are never unveiled. Although during the years several hypotheses have associated the archetype of Dracula as a symbol of manifest resistance to the advance of capitalism, or to the role of women in Victorian society, less attention has been paid to the idea that hospitality may be the primary criterion for defining why Dracula is an evildoer. The West has developed a sense of hospitality which is specific to Europe. Travellers are sacred persons who are protected by Gods. To avoid disasters and calamities, hospitality should be offered to aliens in the same way that God will provide us with hospitality in the hereafter. The roots of evil may be found in the violation of the sacred-rules of hospitality.
\end{abstract}

KEYWORDS hospitality, perverse hospitality, hostility, Dracula, evil, traveler

1 Maximiliano E. Korstanje is professor at the Palermo University, Buenos Aires, e-mail: maxikorstanje@arnet.com.ar 


\section{INTRODUCTION}

Over the centuries Dracula has caused fear and fascination to different audiences and generations in the West. Doted on for his outstanding powers, Dracula not only survives by contaminating others or taking their lives but is also immersed in a state of eternal mourning because of the death of his wife. This romantic touch corresponds to the socio-cultural context in which Bram Stoker wrote his masterful work. A shady character that walks about at night, or a demon, Dracula is still rooted in the social imagination of western civilization and is well-known as the archetype of vampires. These creatures, first and foremost, are 'dead in life', condemned to the shadows as "evildoers". Since vampires have a dual nature which is very hard to classify, they have captured the attention of social sciences such as philosophy, anthropology and sociology. F. Gil Lozano \& J Burucua (2002) explain that Bram Stoker, the brilliant novelist, projected in his text the pervasiveness of his 'proper' daily life, in which a passion for literature was combined with theater at night. As an archetype of evil, the myth of Count Dracula embodies the legends of Elizabeth Báthory, a bloody Countess who loved to murder maidens to obtain "the formula of eternal life" with Vlad Tepes, a revolutionary Romanian hero who struggled against the Turks. The combination of violence and an appetite for blood were a perfect product for European audiences and transformed Stoker's book into a best seller. This context begs more-than-interesting questions, such as what type of fear does Dracula engender, what are the cultural values that this strange Count emulates, and why does he attack at night?

In this essay review, which is the subjective opinion of the author, we will explore the mythological archetype of Dracula, as well as his predilection for violating the pact of hospitality. Likewise, our thesis is framed in the following way: Societies construct symbolic platforms to legitimate their economic production such as stories, legends and myths. Far from being subjective and speculative, myths are vital to illuminate paths for present generations. As founding fathers have overcome dangers and obstacles, the following members of society should follow their examples. Far from what public opinion holds, myths are often reproduced through diverse means. Dracula not only fulfills the problem of what Kristeva dubbed "perverse hospitality", but also represents a diagnosis of the capitalist ethos. He seduces his victims by offering them diverse banquets, food and even sex, in doing so using hospitality to meet his perverse needs.

His real interests are never unveiled. Although during the years several hypotheses have identified the archetype of Dracula as symbol of manifest 
resistance to the advance of capitalism, or to the role of women in Victorian society, less attention has been paid to the idea that hospitality is the primary criterion for defining why Dracula is an evil-doer. The West has developed a sense of hospitality which is specific to Europe. Travelers are sacred persons who are protected by Gods. To avoid disasters and calamities, hospitality should be offered to aliens in the same way that God will provide us with hospitality in the hereafter. The roots of evil may be found in the violation of the sacred-rules of hospitality

\section{CONCEPTUAL DISCUSSION (HOSPITALITY)}

The boundaries of authority are determined by the borderlands which represent the connection between us (internal) and them (external). Julia Kristeva (1965) contended that 'aliens' are killed by their own mother (the motherland) when they leave behind a past of privations and suffering to embrace a new future in a new land. Hospitality serves as a social institution for recognizing the philosophical ontology of these outlanders. An encounter between hosts and guests is a pretext for celebrating with a banquet which is a form of gift-exchange that helps cement mutual trust. Three types of such encounters may be differentiated between. They are the following:

Paternalist - this signals broad, charitable and compassionate sentiments and occurs when the Other is subordinated to the host's desires. This is the case whenever the Other's customs are allowed, but only for the purpose of over-valorizing the host's own customs as superior.

Paranoiac - when the Other is seen as an invader or intruder whose presence is undesired. Xenophobia is one of the commonly-shared expressions of this subtype.

Perverse (or evil) - this exhibits the darkest side of hospitality, where the guest is welcomed at first sight, only to be enslaved later. The perverse host never confesses their own interest.

Historically, the "covenant of hospitality" functioned as an inter-tribal common defense mechanism for activating reciprocity throughout Europe. During periods of peace, hospitality encouraged the circulation of goods and persons by means of a gift-exchange mechanism. It was of paramount importance to protect travelers who arrived from another friendly community. In popular parlance, an alien was sent by the Gods to test the hosts' integrity and virtue. Some cultures envisaged that Gods took the shape of foreign travelers. Deepening on how they were treated, the community might obtain protection or immunity from hostile nature. Our ancient ancestors strongly 
believed that natural disasters resulted from a lack of hospitality to aliens (Derrida, 2006; Amuquandoh 2010; Innerarity 2008; Korstanje 2010). Since hosts and guests are not familiar with the other's interests, both are subject to a temporal pact of non-aggression. As a controlled risk, hospitality thus exerts disciplinary control over new-comers, making an encounter as little traumatic as possible. To some extent, not surprisingly, hospitality has played a vital role in the configuration of nation-states to date.

Without any apparent cause, hospitality may turn to hostility; both words share the etymological root hospitium which is formed by the terms pet and ospes, meaning "what belongs to the Master"; more precisely, there is a political nature which is inferred in the temporal rights that travelers have: not to be killed abroad (Balbin Chamorro 2006). The idea of being buried outside their home territory is one of the most frightful anxieties ancient citizens had. This is the concern that prompts Jacques Derrida to write about hospitality. The philosopher alludes to two types of hospitality for better understanding the authority of state and law over the subject. Whilst 'restricted hospitality' signals the benefits guests receive if they pay for them, a more universal subtype of hospitality creates the conditions for 'cosmopolitanism', where the right of asylum must be guaranteed to all, no matter their culture, wealth and lineage (Derrida \& Dufourmantelle, 2006). If newcomers lack money to pay for protection, they are traced and imprisoned by the police. At a closer look, one might frame the concept of hospitality as a form of social control, a legacy which has been triggered by Marxist and post-Marxist studies, or simply view the hospitality as a sign of the gift-exchange stage of reciprocity (Lynch et al, 2011).

Not surprisingly, some anthropological voices reveal that ostentation and emulation in spaces of hospitality is promoted by offering the guest superiority over the hosts; no matter what the economic conditions, a host will look to provide its best food, drink and shelter to enhance their own status and class. This logic not only activates the social mechanism of control, but also a specific domain of economy where goods are exchanged in limited circles (Sahlins 1972). Hospitality takes root in diverse forms in our hyperglobalized economies. Jennifer Germann-Molz stresses the importance of social networks which serve as platforms of togetherness, self-oriented to produce hospitality. This, for example, is the case of couchsurfing.org, which through cyberspace offers a great variety of opportunities for participants to contact others (hosts) while traveling. The process consists of using a platform by which members (as guests) arrange to 'surf' at hosts' homes. This engenders serious risks in view of the fact that the hosts and guests have no previous familiarity with each other. The project was developed by 
Australian surfers to obtain free lodging when they were abroad. Now it has become a global network that connects people in search of new experiences. At the time when the host offers hospitality to the guest, the cultural exchange starts. Safety is a vital element of hospitality because it regulates the trust that both guests and hosts exchange. Without safety, hospitality is hemmed into a situation of ethical dilemma (Germann Molz, 2014).

In this respect, Zygmunt Bauman claims that hospitality and mobilities, far from being offered to all citizens, are selected and offered to a privileged group, a global elite. The benefits open to the global aristocracy who can afford to visit outstanding places contrast with the restricted realities of migrants who are monitored, traced and disciplined according to the logic of the market. The spirit of the global market is to exploit not only workers, but also consumers (Bauman, 1998a; 1998b). It is unfortunate that the technological advances that have accelerated mobility over the last years have not expanded hospitality to other countries. Although tourism is one of the most promising industries, developed nation states securitize their frontiers by imposing diverse surveillance mechanisms. As Korstanje puts it, today's hospitality is derived from systems of migration among nations that facilitate the mobilities of passengers, as well as commit to protect them during their sojourns. Asymmetries and reciprocities concerning how visas are conferred or restricted to aliens bespeaks the old pact of hospitality (Korstanje 2011a).

\section{HOSPITALITY AND HOSTILITY}

The contrast between hospitality and hostility has been widely examined by Jacques Derrida. In his book Of Hospitality he initiates a discussion about how to understand hospitality from a philosophical perspective. Interestingly, the first point Derrida analyzes concerns foreigners (xenos). In the dialogues of Plato, the foreigner is frequently represented as that one who asks about others. As a consequence, the foreigner shakes the reigns of dogmatism and the politics of community. Derrida considers as guests those who come accompanied with a different language and culture to that of the host community. Such differences as these not only remind us of our own prejudices but also re-elaborate a new sense of meaning for our societal institutions. The existence of such foreigners threatens paternal hegemonies and questions the significance of hospitality. However, in his work The Sophist Plato refers to foreigners as outsiders who do not speak and share my understanding; needless to say, this thesis is in sharp contrast with that of Parmenides who argued that the universality of knowledge does not recognize other languages or nations; 
the status of 'being a stranger' seems to be circumstantially irrelevant.

How may we interpret this? Hospitality is offered (or not offered) to a foreigner and his personal property. In the same context, we understand the world through questioning the knowledge and experience that others bring to us. The stranger splits our world into two parts.It is often assumed that our identity is born in the heart of our family, city or nation; however, for Derrida this is not possible since our identity is formed by the inception of "others." This way, only outsiders may know, see, and ask for an explanation of our customs and habits that goes beyond the limits of ethnocentrism. If we look down on others who look different to us, then we also despise ourselves. Derrida suggests that the question is conceptually linked to the foreigner. As with the foreigner, the question may (or not) be hosted; on some occasions, the question would be welcome, but under others, the situation may be rejected. Accordingly, we may bring our hospitality before a question. To be more exact, in The Apology by Plato Socrates speaks to citizens and judges and argues that he does not understand the language of the trial. Socrates declares himself not guilty since he does not share the same rhetoric as the judges. Socrates faced the Athenian court of law as a "foreigner." Following this line, Derrida maintains that, "among the problems we handle here, there is a foreigner who unable to speak the language of the host country, who may be rejected or injured without any type of defense."

The language of the host involves violent and sudden interrogation since it imposes the home owner's interpretation of events. The foreigner is forced to adopt another tongue which is not the one he usually speaks or writes. The host's translation is part of his very own abode and, according to Derrida, it is at precisely this point where the opportunity for hospitality arises. The important point for discussion is that, accordingly, two types of hospitality surface: the absolute and the conditioned. "Absolute hospitality demands that the host open the proper home not only to foreigners but also to anonymous Travellers who are unknown to them. This way, I am obliged to let them to enter but to ask for reciprocity." In order for the discussion to be resumed, a couple of conditions must be addressed to make hospitality possible: what is your name, and where do you come from?

As a consequence, Derrida is convinced that the rights of the foreigner may be found within hospitality itself. If a foreigner arrives to a country he is immediately subject to the laws of the host even when they are unknown to him. Each foreigner is constructed from the host country's "ethos." Based on Hegel's explanation, Right is determined by family, bourgeoisie society and by Estate; these limits set up the liaison between hospitality and hostility. At first instance, hospitality infers a certain level of protection, whereas hostility 
refers to the violence directed towards xenos (those who do not belong to a group). Is Dracula an archetype determined by violence, and thus Xenos?

\section{EXPLORING THE ARCHETYPE OF DRACULA}

The archetype is defined as a platform of multi-cultural elements that are one-sided and are organized to instill a message to a community. As social constructs, archetypes are determined by a rich set of sources which range from literature to television. Social scientists should delve into these archetypes to better understand how a community feels, thinks and counteracts in certain contexts (Lind, 1993; Skoll \& Korstanje 2014).

Specialists agree that Stoker was influenced by two stories that are embedded in the folklore of Eastern Europe. Elizabeth Báthory was a countess (15601614) who was considered one of the most prolific serial killers of medieval times. Underpinned by the belief that fresh blood would delay the passing of time, she invited in hungry girls. Once in her castle, they were tortured and bled to death. Following her advisors (witches), who convinced her that she could live forever if she took baths of blood, Bathory and her servants committed diverse atrocities with the adolescent daughters of local peasants. Apostatized as if she were possessed, the countess soaked in a bathtub full of blood. It was unfortunate that these sadistic rites were not enough to hinder the passing of time, even for Bathory. Her witches advised her that the problem was that the peasants' blood was of lower quality than that of the nobility. Instead, she should sacrifice young maidens from the lower-nobility. Needless to say, this was the start of the end for Bathory who was later accused before the King. Disposed of all her property, she was convicted and sentenced to be confined in isolation in one of the rooms of her castle for the rest of her natural life. The other legend that impressed Stoker was the story of Vlad Tepes 'the impaler', well known for his cruelty and mercilessness towards his enemies. The prince of Wallachia (1431-1476) was a member of the house of Dragon (house of Basarab), from whence the name "dracule" originates, later adopted by Stoker as "Dracula". Far from being a monster, Tepes struggled against the advance of Ottomans. Historians believed that the Ottomans had hosted Tepes with his father when he was still a child after which Tepes developed a strong hatred against them. No less true is that in extremely violent times, Tepes's behavior was no so different from that of the other princes. The degree of sadism with which he used to impale the enemies of the kingdom was combined with the unnamable brutality which he employed to keep power in his inner circle. Stoker's imagination and sensibility were combined in the literary 
product Dracula, a gothic horror novel which has acquired a great variety of interpretations and meanings in view of the passing of generations. What is more important to discuss is to what extent Dracula not only reflected the ebbs and flows of Victorian society and its economic problems, but also the way the West conceived of otherness, which varied in its flexibility over time. The archetype of Dracula, from our perspective, speaks to us of the restricted hospitality that western societies offer to aliens. One problem for the British Empire was to understand politically the immigrants (as new comers) that had resulted from its foreign relationship with its colonies, as embodied in the tale of Dracula. Underpinned by the belief that strangers are evil-doers, just as in the story of Dracula, the British Empire developed an ethnocentric view of the World which restricted their offering of hospitality. This is the point of entry that underlies the archetype of Dracula which remains unresolved by experts.

\section{WHAT IS EVIL? (A LACK OF HOSPITALITY)}

The supposed existence of evil figures and their importance in Christian cosmology not only emphasize the limits of our omnipotence but also remind us of the problems that rational thought faces in preventing contingency: those negative phenomena which may destroy our civilization at any time. As Keith Thomas put it, it is no surprise that evil is linked to our own frustrations, disasters and the death of relatives. Whenever man cannot control his environment, the concept of evil emerges to counter psychological frustration. Psychologically, we confer our frustration on an "archetype" (of evil) which serves as a scapegoat (Thomas 1978). In this vein, Jean Markale (2006) argues convincingly that demons and evildoers take the form of rebels who are set up in opposition to God's power. These narrative explains, Markale adds, what people should do when things do not work. Demons are employed as scapegoats to purify the community in the context of disasters in order that society should not disintegrate. Clearly, demons violate the will of their hosts when they take possession of a body. A possession, similarly to manipulation or seduction, takes control over of victim's body, infringing the right of the master to enter in. It is typical to think that vampires cannot enter in whenever owners reject them. Nonetheless, the super-powers of a vampire lead them to seduce their victims through the creation of a hypnotic state. The allegory of blood, historically rooted in the principle of hospitality, is associated with free will. When the vampire sucks the last drop of its victim's blood, its takes control of its mind. This discourse, which centers on the western concept of hospitality, is present throughout horror movie genre. 
It is hypothesized that Dracula represents the double-edged fascination that societies have with blood and power. Blood serves not only as the protective cocoon of lineage, but its allegorical meaning helps one to understand death itself. On behalf of "blood", violence is exerted in order for the legitimacy of a clan to be maintained. As a symbol of life and death, blood has fascinated European societies from time immemorial. Following Laura Cilento's development, the story of Dracula emulates one of the most famous modern myths; a dissuasive narrative that captivated the attention of the entertainment and cultural industry. The idea of the sublime not only creates panic because it cannot be controlled, but also because it is beyond our willpower. In other terms, Dracula is framed in a controlled scenario wherein terror becomes pleasure. Since we know that Dracula is an invention, a fiction, our own ontological existence is not in danger. In fact, horror movies stimulate the production of adrenaline through their portrayal of events, but as fearful as the experience may be, viewers remain safe. Do horror movies represent repressed sadism?

It is important not to lose sight of the fact that we cannot be accused of compliance in sadistic acts and participating in another's suffering since horror movies are fictional. Conversely, if the horror we watch on TV were real, we would recoil from it. Psychologically, we judge to be "disgusting" the torture of people if it is real, but enjoy the same when portrayed in action movies. The fictitious nature of the medium confers to the self a sense of control, irrespective of the degree of violence. This opens the door to the advent of a philosophical paradox: at the same time as we approach reality we desire more fiction in our lives (Worth 2005). A great variety of literature and literary evidence shows that the legend of the Vampire may be rooted in pre-industrial Europe some time before Stoker's novel was written. These texts were inspired by two main cultural components: a fear of contagion was conjoined with the desire to avoid contamination. In the modern era, while some studies have attempted to demonstrate that we have made Dracula a movie-star because of our irreversible fears of an HIV epidemic, as well as with problems implementing preventive policies with regard to sex (Giordanino 2002), others focus on the transylvanian count as the inception of late-modernity, where the self is unable to construct its identity without the contribution of the view of the other (Delgado 2002). Certainly, Dracula is not only associated with power since he is a nobleman (like Báthory) but he also is an alien in Victorian England. The allegory of the vampire has been constructed according to the cultural problems of England that concern the acceptance of strangers. Just as colonial assets signified that the world beyond the boundaries of the British Empire was an unsafe place to visit, otherness was 
portrayed as an "undesired guest". As such, the unworthy guest, the archetype of the Vampire, shares some features with witchcraft. Alejandro Campagne writes that both the vampire and the witch have evolved through stories in which women were considered the agents of power, but from the XVth century onwards the meaning of witchcraft changed forever. Radically altered from the ancient conceptualization (which posited a differentiation between a witch and a sorcerer) the modern understanding of witchcraft alludes to the contact of women with the devil. These meetings, which naturally take place at night, serve not only to release women from their pact with Christ but also fulfil all their desires. Irreversible in nature, the speculative existence of witches engendered serious concern for the medieval church in Europe. Following Campagne, if witches devour children to maintain their power over a community (as vampires do) this is associated with the consumption of blood. Vampires and witches are "demons" that exploit the more vulnerable sector of the population to survive. This represents a disciplinary mechanism to control the "non-European" other in the context of the (post) discovery of the Americas (Campagne 2002).

In sharp contrast to Campagne, Korstanje establishes that witchcraft is constituted by means of the attachment of women to evil. An ancient fear of offspring death which endangers the symbolic reservoir of generations generates the need for humankind to construct a conception of evil. Societies appeal to the struggle against evil, reacting to imbalances in fertility systems or economic gift-exchange logic (Korstanje 2009; 2011; 2013b). The following axiom explains the allegory of evil. Originally created to protect humankind, evildoers have fallen and now embrace corruption, arrogance and envy. This situation is applicable, from Lucifer's rebellion in heaven to the love of Dracula. Although their instrumental goals leave them far removed from a state of goodness, corruption leads demons to be considered staunch enemies of society. Their original function is upended by greed. Moved by ambition, the angel which betrays its essence (the purpose for which God created it) and the police-officer who manages a criminal network evince the roots of evil (Korstanje 2013a).

\section{BREAKING THE RULES OF HOSPITALITY}

Classical literature and mythology is fraught with examples of what happens when the sacred rule of hospitality is broken. Helen of Troy, kidnapped by her lover Paris after enjoying a banquet, not only triggered a bloody war but also the decline of Troy as well as Hector's death. The same applies to 
other heroes who rejected hospitality or were killed by their hosts while they were sleeping. Faunus attempted unsuccessfully to kill Heracles in his bed, whereas Samson was deceived by Delilah. Whenever the rules of hospitality are broken evilness surfaces.

As earlier discussed, it is noteworthy we can better understand Dracula not necessarily through his personal characteristics, but by his inability to offer "honest hospitality". To some extent we strongly believe that the specialized literature places more emphasis on his appetite for blood instead of any malevolent intent to attack guests. The thesis for discussion in this text rather consists of the proposition that the roots of evil are found in a lack of hospitality.

In earlier studies, Korstanje and Olsen (2011) \& Korstanje \& Tarlow (2012) examined in detail the synopsis of some horror films which are a part of the horror genre in US. The specialists found that one of the most troubling aspects these films evidence is fear of strangers. In The Hills have eyes, Hostel, or The Texas Chainsaw Massacre, the setting is a faraway landscape such as a desert or a forest, beyond the boundaries of civilized society which is associated with an urban, densely-populated city.

Maximiliano Korstanje \& Daniel Olsen go on to say that:

"The premise of these movies was that American tourists, with promises of sex and other hedonistic experiences are lured to a remote hostel in Slovakia where they are captured and given over to sadist millionaires who pay for the right to torture and kill these tourists during their murder-vacation. These two films are underscored by a number of discourses previously touched upon. For example, these movies illustrate the vulnerability of strangers in East countries- a post-Cold war view in Western imagination and political discourse. Also, in both films there was an over-valuating of millionaires for the "American tourist" over tourists of other nationalities. In addition, while the American tourists were seduced by the lure of sexual and other hedonistic pleasures (hospitality), this hospitality was suspended, as both the local tours guides and police were complicit in arranging these all-inclusive package tours for the sadist millionaires to play out their cruel and perverted fantasies in a display of extreme sadism against the tourists. As such, if these tourists had been part of an all-inclusive package tour rather than deciding to travel on their own the dangers they faced would have been mitigated and hospitality 
may not have been suspended. This reinforces the view that peripheral destinations are not only dangerous but also sites of conquest, and as such the Hostel movie franchise present two typologies of tourists: the predators, whose conquest are the foreign tourists to Slovakia, and the prey, foreign tourists that experience danger and loss of life due to the inhospitable peripheral location they frequented". (Korstanje \& Olsen, 2011, p. 311)

Throughout whole horror movies, victims are vulnerable backpackers and tourists who desire contact with nature and visits to utopian and remote destinations. It is unfortunate that nothing prepares them for what occurs. A third actor goes on stage, offering a banquet to the young newcomers that serve as a staged introduction to their own death. After a long period of travel, the host offers not only protection but also food, sleep and shelter for the "tired tourist". On the one hand, the elementary forms of hospitality which may contrast with the rigors of working life consist of food, sex and entertainment; goods which lay-people may be deprived of on a daily basis due to the nature of the productive system in which they are enmeshed. During the rites of hospitality, the guest does not know the intention of the host, nor the environment; thus their state of vulnerability increases. Metaphorically speaking, if a just King reconciles the risk in the encounter, the evildoer breaches the sacred right of hospitality, attacking the hosts under inferior conditions. In perspective, evil is thus based on a lack of hospitality to strangers who may be assassinated or wounded far from home. This is the commonality shared by witches, Dracula (or any other vampire) and E. Báthory (Korstanje, 2013b; 2010). These actors seduced their victims by offering food or sex, but ultimately their intentions were not good.

As a lucid writer, Bram Stoker and his novel introduce us to the irreconcilable world of trust and nobility. The main thread of the argument rests on the ability of Dracula to cheat his victims. Similarly to what we have discussed above, Stoker's imagination offers a solution to the dilemma of hospitality in the two parts of the book. A young lawyer, Jonathan Harker, leaves the home comforts of England to visit Transylvania in the "Carpathian Mountains". Although Dracula presents as a skilled and educated person whose generosity has no limits, deep under these seemingly well-meaning gestures is a malevolent creature. Beyond the offering of banquets and the company of many willing and beautiful maidens, Harker realizes that Dracula harbors an evil nature. The guest who consumes everything that he is societally deprived of - rest, food and women - with the passing of days becomes a prisoner of his 
master. The vamps suck the blood of our British lawyer, keeping his body in a state between life and death. Dracula kidnaps a child to give to the vamps instead of Harker, who paradoxically becomes food for the Vampires. The mother of the child attempts to enter Dracula's Castle but she is attacked and devoured by wolves. This passage tells us about the bondage between the individual and its mother. While hospitality emulates the sacred relationship between self and its care-takers, the hospitality offered by Dracula runs in the opposite direction. The filial bond is not only broken by hostility but also by "evil-doers". Once Dracula goes to Europe, Harker escapes from his slavery in this dark sanctuary. Concerned to protect his wife Mina, Harker returns to England, as Dracula, who arrives as a rich stranger, settles in next to Mina. Once again, Dracula follows the principle of hospitality in allowing himself to be accepted by Mina Murray's family. This permission allows the Count to take the life of Mina's best friend Lucy, and her own mind. Mina is seduced and finally hosted by Dracula who leaves his residence in England. She is the only person who receives genuine hospitality from Dracula, simply because he falls in love with her. This connotes the idea that hospitality and love are inextricably intertwined; however, much more work should be undertaken to explore this proposition.

\section{CONCLUSION}

Last but not least, Stoker's development is evidence that breaching the principle of hospitality is the main reason why Dracula is a villain, a monster, is without mercy; this may even be the reason for his malice. The count systematically satisfies his vile instincts through infringing the sacred right of protection granted to the guest through hospitality: this occurs through taking the opportunity to attack the guest while they are sleeping or defenseless. This short essay-review is intended to initiate new discussion in the specialized literature in which hospitality has been ignored as a source of understanding in the construction of the myth of Dracula. Over years and decades, as something more important than a novel, Dracula emulates cultural values that concern the limitations of the West in accepting aliens, as well as the issues surrounding the desire for eternal life. Whatever the case may be, more profound insight should be sought as regards the link between blood and hospitality; however, this should be undertaken using other approaches. 


\section{REFERENCES}

Amuquandoh, F. E. (2010). Lay concepts of tourism in Bosomtwe Basin, Ghana. Annals of Tourism Research, 37(1), 34-51.

Balbín Chamorro, P (2006) "Ius Hospitti y Ius Civitatis". Revista Gerión. Vol. 1 (1): 207-235

Bauman, Z. (1998a). Globalization: The human consequences. New York, Columbia University Press.

Bauman, Z. (1998b). On glocalization: Or globalization for some, localization for some others. Thesis Eleven, 54(1), 37-49.

Campagne, F. A (2002) "Vampirismo y Estereotipo de la Bruja en la España de los siglos XV y XVI". En Zilele Dracului. Las Diversas Caras del Vampiro. Burucúa y Gil Lozano F. Buenos Aires, Eudeba, pp. 31-43.

Cilento, L (2002)" Drácula y Lo Gótico como canón Estético" En Zilele Dracului. Las Diversas Caras del Vampiro. Burucúa y Gil Lozano F. Buenos Aires, Eudeba, pp. 47-54.

Delgado, C (2002) "Drácula entre el ser y la nada". En Zilele Dracului. Las Diversas Caras del Vampiro. Burucúa y Gil Lozano F. Buenos Aires, Eudeba, pp. 105-116

Derrida, J., \& Dufourmantelle, A. (2000). Of hospitality. California, Stanford University Press.

Germann Molz J. (2014) Travel Connections. Tourism, Technology and Togatherness in a mobile World. Abingdon, Routledge.

Gil Lozano, F y Burucúa J (2002). “Introducción”. En Zilele Dracului. Las Diversas Caras del Vampiro. Burucúa y Gil Lozano F. Buenos Aires, Eudeba, pp. 13-16.

Gil Lozano, F y Burucúa J (2002) "Drácula y su historia” En Zilele Dracului. Las Diversas Caras del Vampiro. Burucúa y Gil Lozano F. Buenos Aires, Eudeba, pp. 17-30.

Giordanino, P. (2002). "Los Vampiros antes de Drácula”. En Zilele Dracului. Las Diversas Caras del Vampiro. Burucúa y Gil Lozano F. Buenos Aires, Eudeba, pp. 55-70.

Innerarity, D. (2008) Ética de la Hospitalidad. Barcelona, Península.

Korstanje, M. E. (2009). "El Mal y La Posesión Diabólica: Un análisis crítico sobre los conceptos de contaminación y tabú". Revista de Antropología Experimental, 9(13), 179-189.

Korstanje, M (2010) "Formas Elementales de la Hospitalidad". RBTUR: Revista Brasilera de Pesquisa em Turismo. Vol 4 (2): 86-111

Korstanje, M. (2011a). Reciprocity, hospitality and tourism. An examination of Marshal Sahlins's contributions. European Journal of Tourism, Hospitality and Recreation, 2(2), 89-103.

Korstanje, M. (2011b). "Rebelión: una Aproximación Teórica”. International Journal of Zizek Studies. Volume 5, Issue 4. December 2011. (pp. 1-43). Disponible en http://zizekstudies.org/index.php/ijzs/index. University of Leeds, UK

Korstanje M (2013a) "Las Funciones del Mal: un debate ético sobre la ontología del mal”. Reflexiones Marginales, Vol. 3 (20): 1-8 
Korstanje, M. E. (2013b). "Hansel \& Gretel, Cazadores de brujas". Nómadas. Revista Crítica de Ciencias Sociales y Jurídicas, 37(1), 307-312.

Korstanje, M. E., \& Olsen, D. H. (2011). "The discourse of risk in horror movies post 9/11: hospitality and hostility in perspective". International Journal of Tourism Anthropology, 1(3), 304-317.

Korstanje, M. E., \& Tarlow, P. (2012). "Being lost: tourism, risk and vulnerability in the post-'9/11'entertainment industry". Journal of Tourism and Cultural Change, $10(1), 22-33$.

Kristeva J. (1991) Extranjeros para nosotros mismos. Barcelona, Plaza \& Janes Editores.

Lind, H. (1993). The myth of institutionalist method. Journal of Economic Issues, $1-17$.

Lynch, P., Molz, J. G., Mcintosh, A., Lugosi, P., \& Lashley, C. (2011). Theorizing hospitality. Hospitality \& Society, 1(1), 3-24.

Markale J. (2006) Les Revoltes de Dieu. Buenos Aires, Ateneo.

Sahlins, M (1992) Stone Age Economics. London, Routledge.

Skoll, G., \& Korstanje, M. (2014). The Walking Dead and Bottom Days. Cultural Anthropology, 11, 23.

Thomas, K (1978) Religión and the Decline of Magic. London, Penguin Books.

Worth, S (2005) "The Paradox of Real response to fiction". In The Matrix and Philosophy. Edited by William Irwin. Chicago, Open Court, pp. 178-201 